\title{
FAKTOR-FAKTOR PENENTU TINGKAT PEMAHAMAN AKUNTANSI
}

\author{
Edy Suprianto \\ Fakultas Ekonomi, Universitas Islam Sultan Agung \\ edy_2806@yahoo.co.id \\ Septian Harryoga \\ Fakultas Ekonomi, Universitas Islam Sultan Agung
}

\begin{abstract}
Framework for the Development of Accounting Education Research which is promulgated by the American Accounting Association (AAA), state that special research for accounting education is a need. Tikollah et al. (2006) found that the degree of accounting knowledge is increased by emotional intelligence and students' self-confidence. This study tries to evaluate the effect of emotional intelligence, study behavior, and culture to the degree of accounting knowledge that is moderated by self confidence. The research population is all of the students in Semarang. While the samples were collected using purposive sampling method. There are two criteria to choose the samples; which are (1) student from the accounting department in sixth until eighth semester, and (2) the students in Sultan Agung Islamic University, Diponegoro University and Semarang State University. Based on these criteria, the samples are counted by 96 students. The result revealed that emotional intelligence and study behavior has a significant positive effect to the degree of accounting knowledge. Culture does not have a significant effect to the the degree of accounting knowledge. Moreover, the research could not provide evidence that self-confidence is a moderating variable to increase degree of accounting knowledge.
\end{abstract}

Keywords: emotional intelligence, study behaviour, culture, accounting knowledge, self-confidence

\section{PENDAHULUAN}

Perguruan tinggi merupakan jenjang pendidikan tertinggi dalam sistem pendidikan nasional Indonesia, yang diharapkan akan menciptakan manusia berkualitas dan intelektual sehingga mampu mengubah masa depan bangsa yang lebih baik. Hal ini juga sesuai dengan yang dinyatakan oleh Suwardjono (2004) bahwa mahasiswa yang belajar di perguruan tinggi dituntut tidak hanya mempunyai keterampilan teknis tetapi juga memiliki daya dan kerangka pikir serta sikap mental dan kepribadian tertentu, sehingga mempunyai wawasan luas dalam menghadapi masalah-masalah dalam dunia nyata (masyarakat). Salah satu faktor yang dapat 
mendukung keberhasilan pendidikan tinggi akuntansi adalah sikap, mental serta kemampuan membaca diri sendiri. Dalam kaitannya dengan aspek psikologi personal, pengertian tersebut sering diistilahkan dengan emotional quotient (EQ). Selanjutnya penelitian ini mencoba menganalisis bagaimana perguruan tinggi dapat mencapai tujuan yang diharapkan tersebut.

Menurut Goleman (2000), kecerdasan emosional merupakan kemampuan merasakan dan memahami secara efektif dalam hal penerapan daya dan kepekaan emosi sebagai sumber energi, informasi, koneksi dan pengaruh yang manusiawi. Dengan kemampuan tersebut maka mahasiswa akan mampu mengenal siapa dirinya, mengendalikan diri, memotivasi diri, berempati terhadap lingkungan sekitarnya dan memiliki keterampilan bersosialisasi berdasarkan kemampuan untuk meningkatkan kualitas pemahaman mereka tentang akuntansi. Kemampuan ini mendukung mahasiswa dalam mencapai tujuan dan cita-citanya.

Goleman (2000) menyatakan bahwa kemampuan akademik bawaan, nilai rapor dan prediksi kelulusan pendidikan tinggi tidak memprediksi seberapa baik kinerja seseorang sudah bekerja atau seberapa tinggi sukses yang dicapainya dalam hidup. Kecerdasan emosional menentukan seberapa baik seseorang menggunakan keterampilan-keterampilan yang dimilikinya, termasuk keterampilan intelektual. Paradigma lama menganggap bahwa kondisi ideal adalah adanya nalar yang bebas dari emosi. Namun paradigma baru menganggap perlunya kesesuaian antara kepala dan hati. Hal ini didukung oleh hasil survei yang dilakukan di Amerika serikat tentang kecerdasan emosional, yang menjelaskan bahwa apa yang diinginkan oleh pemberi kerja tidak hanya keterampilan teknik saja, tetapi juga dibutuhkan kemampuan dasar untuk belajar dalam pekerjaan yang bersangkutan. Kemampuan dasar tersebut diantaranya adalah kemampuan mendengarkan dan berkomunikasi lisan, adaptasi, kreatifitas, ketahanan mental terhadap kegagalan, kepercayaan diri, motivasi, kerjasama tim dan keinginan memberi kontribusi terhadap perusahaan. Seseorang yang memiliki kecerdasan emosional yang tinggi akan mampu mengendalikan emosinya sehingga dapat menghasilkan optimalisasi pada fungsi kerjanya.

Selain faktor kecerdasaan emosional, penelitian ini juga dimaksudkan untuk mencari jawaban atas fenomena tersebut dengan menambahkan variabel perilaku belajar mahasiswa akuntansi di perguruan tinggi. Perilaku belajar mahasiswa dapat berupa kebiasaan mengikuti pelajaran, kebiasaan membaca buku, kunjungan ke perpustakaan dan kebiasaan menghadapi ujian. Variabel perilaku belajar di perguruan tinggi ini merupakan pemikiran Suwardjono (2004) tentang perilaku belajar di perguruan tinggi, yang menggugat sistem pembelajaran perguruan tinggi yang belum memenuhi standar proses belajar mengajar dengan benar dan ideal, sehingga hasil belajar di perguruan tinggi tidak maksimal. 
Kegiatan belajar mengajar merupakan suatu privilege, karena hanya orang yang memenuhi syarat saja yang berhak belajar di perguruan tinggi. Privelege yang melekat pada mereka yang belajar di suatu perguruan tinggi tidak hanya terletak pada kondisi fisik dan sumber daya manusia yang disediakan saja, tetapi juga pada pengakuan secara formal bahwa seseorang telah menjalani belajar dan pelatihan tertentu (Suwardjono 2004).

Hamalik (2001) dalam Suyanti (2006) menyatakan bahwa salah satu faktor yang bersumber dari dalam diri sendiri adalah kebiasaan belajar atau perilaku belajar. Perilaku belajar merupakan kebiasaan belajar yang dilakukan oleh individu secara berulang-ulang sehingga menjadi otomatis atau berlangsung secara spontan. Perilaku belajar tidak dirasakan sebagai beban melainkan sebagai kebutuhan. Hal ini tercipta karena secara terus-menerus dilakukan dengan bimbingan dan pengawasan serta keteladanan dalam semua aspek dan kreatifitas pendidikan. Selain itu terdapat kondisi dan situasi perkuliahan yang diciptakan untuk mendukung berlangsungnya kreatifitas dan kegiatan-kegiatan lain dalam konteks pembelajaran.

Boyer (1990) dalam Suyanti (2006) menyatakan bahwa "the work of professor consists of four overlaping function: the advancement of knowledge, the synthesis of knowledge, the application of knowledge, and the communication of knowledge to those world learn”. Dengan demikian, pendidikan akuntansi mencakup dimensi pengajaran (teaching) dan riset. Riset dalam pendidikan akuntansi bukan semata-mata mengajarkan hasil penelitian kepada mahasiswa, tetapi lebih jauh memahami perilaku dan presentasi mahasiswa melalui riset yang pada akhirnya disampaikan kepada mahasiswa dalam bentuk kebijakan, misalnya seperti kurikulum (Albrecht et al., 1994 dalam Suyanti 2006).

Hal ini sejalan dengan usulan Framework for the Development of Accounting Education Research yang dikeluarakan oleh American Accounting Association (AAA). William et al. (1985) dalam Suyanti (2006) menyatakan adanya kebutuhan riset pendidikan akuntansi tambahan tentang pengaruh demografi terhadap prestasi akademik mahasiswa. Namun setelah di tijau dari berbagai aspek, lingkup demografi masih terlalu luas untuk diteliti. Oleh karena itu lingkup demografi akan diturunkan menjadi tataran empiris sesuai dasar penelitian sebelumnya yang menyebutkan bahwa faktor budaya yang merupakan salah satu dimensi dari demografi yang mampu memengaruhi tingkat pemahaman akuntansi (Gray 2001 dalam Suyanti 2006).

Terdapat banyak perbedaan mengenai budaya dalam berperilaku seperti dalam cara berpikir, memahami dan berperilaku budaya. Sebagian besar konsep tersebut berasal dari ranah antropologi, namun hanya sedikit kesepakatan mengenai definisinya (Choi 1995 dalam Muhibbin 2000). Budaya didefinisikan sebagai kompleksitas yang mencakup pengetahuan, kepercayaan, seni, moral, hukum, adat, kemampuan lain dan kebiasaan yang diakuisisi oleh manusia sebagai anggota 
masyarakat (Tylor 1871 dalam Slameta 1991). Kroeber dan Kluckhohn (1952) dalam Slameta (1991) menunjukkan bahwa budaya dapat dilihat sebagai produk perilaku yang membentuk perilaku seseorang.

Budaya yang berbeda juga membawa variasi dalam cara dan preferensi siswa dalam belajar. Conlan (1996) dalam Suyanti (2006) menunjukkan bahwa pendekatan belajar yang diadopsi oleh siswa berlatar belakang budaya Asia pada umumnya melibatkan menghafal materi belajar. Sebaliknya, banyak siswa dan orang-orang dari latar belakang budaya barat telah didorong untuk belajar melalui fakta dan pertanyaan pemahaman tentang konsep.

Setiap orang memiliki latar belakang budaya yang dipelihara oleh pengalaman pendidikan mereka, sehingga harus diakui bahwa orang-orang dibentuk oleh kebudayaan walaupun mereka masih individu yang unik. Chin et al. (2000) dalam Suryaningsum et al. (2004) melaporkan bahwa siswa dari latar belakang budaya barat tampak lebih percaya diri dalam menggunakan bahan berbasis web, namun siswa Asia terbukti lebih sedikit mengakses materi berbasis web. Temuan ini menguatkan temuan Hofstede (seperti dikutip dalam Chin et al., 2000) bahwa pembelajaran gaya barat lebih terbiasa berpusat pada siswa, sedangkan pembelajaran dalam budaya Asia lebih berpusat pada guru (Maryati 2008). Dari situasi seperti yang diungkapkan diatas terungkap bahwa masih ada banyak perbedaan mengenai budaya dalam berperilaku, cara berpikir, memahami suatu proses atau fenomena dan berperilaku budaya. Penelitian ini berusaha untuk memperbesar ruang lingkup studi dengan mencakup sejumlah besar mahasiswa di tiga perguruan tinggi di Semarang yaitu Universitas Islam Sultan Agung, Universitas Diponegoro dan Universitas Negeri Semarang. Penelitian ini difokuskan pada mahasiswa akuntansi (S1) guna mengidentifikasi apakah variabel budaya berpengaruh terhadap tingkat pemahaman akuntansi mereka.

Penelitian ini diperkuat dengan adanya kepercayaan diri sebagai variabel moderasi yang mampu memberikan efek memperkuat ataupun memperlemah hubungan antara kecerdasaan emosional, perilaku belajar dan budaya terhadap tingkat pemahaman akuntansi. Secara teoretis, kepercayaan diri memiliki peran yang penting dalam memahami tingkatan akuntansi dimana seorang mahasiswa membutuhkan mental yang kuat guna menunjang kecerdasaan emosional, perilaku belajar dan kemampuan mengintuisi budaya.

Mengacu pada penjelasan yang telah dikemukakan diatas, penelitian ini dimaksudkan untuk menguji pengaruh kecerdasan emosional, perilaku belajar serta budaya terhadap tingkat pemahaman akuntansi. Penelitian ini juga melihat pengaruh kepercayaan diri sebagai variabel moderating yang memengaruhi hubungan kecerdasan emosional, perilaku belajar dan budaya terhadap tingkat pemahaman akuntansi. 


\section{TELAAH PUSTAKA}

\section{Pemahaman Akuntansi}

American Accounting Association mendefinisikan akuntansi sebagai "suatu proses pengidentifikasikan, mengukur dan melaporkan informasi ekonomi, untuk memungkinkan adanya penelitian dan keputusan yang jelas dan tegas bagi mereka yang menggunakan informasi tersebut” (Lutfi 2007).

Pendidikan tinggi mengadakan program pendidikan dengan mengacu pada link dan match. Pengertian link dan match yang dimaksud adalah keterkaitan antara produktifitas baik mencakup kuantitas, kualitas, kualifikasi yang dibutuhkan, dunia industri, masyarakat maupun individu lulusan perguruan tinggi yang bersangkutan. Kenyataannya pasar kerja dan dunia kerja tidak hanya membutuhkan lulusan perguruan tinggi yang semata-mata memiliki penguasaan akan ilmu pengetahuan, tetapi dibutuhkan juga sejumlah kompensasi lain yang tidak dihubungkan dengan ilmu pengetahuan secara langsung. The Institute of Chartered Accountant in Australia (ICAA) dan Accounting Education Change Comission (AECC) yang dibentuk di Amerika Serikat menyatakan bahwa pendidikan akuntansi setidaknya harus dapat mempersiapkan peserta didik untuk mulai dan mengembangkan keanekaragaman karier professional dalam bidang akuntansi. Untuk itu diperlukan tidak semata-mata pengetahuan bisnis dan akuntansi, tetapi juga penguasaan keterampilan intelektual, interpersonal dan komunikasi serta orientasi professional (Trisniwati dan Suryaningsum 2003).

\section{Pengaruh Kecerdasaan Emosional terhadap Tingkat Pemahaman Akuntansi}

Kecerdasaan emosional adalah kemampuan mengenali perasaan diri sendiri dan orang lain, memotivasi diri sendiri serta mengelola emosi dengan baik pada diri sendiri dan dalam hubungan dengan orang lain (Goleman 2000). Kecerdasan emosional memiliki peran lebih dari 80 persen dalam mencapai kesuksesan hidup, baik dalam kehidupan pribadi maupun kehidupan profesional. Untuk menjadi seorang lulusan akuntansi yang berkualitas, diperlukan waktu yang panjang dan usaha yang keras serta dukungan dari pihak lain yang akan memengaruhi pengalaman hidup lulusan tersebut. Pengukuran prestasi akademik juga sama pentingnya untuk mengetahui tingkat keberhasilan yang dicapai mahasiswa dalam belajar (Suwardjono 2004; Goleman 2000). Semakin tinggi tingkat kecerdasan emosional mahasiswa, maka akan semakin tinggi pula tingkat pemahaman akuntansinya (Tikollah et al., 2006). Dari uraian di atas maka hipotesis pertama dinyatakan sebagai berikut.

H1: Kecerdasan emosional berpengaruh positif terhadap tingkat pemahaman mahasiswa akuntansi. 


\section{Pengaruh Perilaku Belajar terhadap Tingkat Pemahaman Akuntansi}

Suwardjono (2004) menyatakan bahwa aspek dalam belajar di perguruan tinggi meliputi makna kuliah, pengalaman belajar atau nilai, konsepsi dosen, kemandirian dalam belajar, konsep memiliki buku dan kemampuan berbahasa. Dalam semua aspek tersebut, pengukuran prestasi akademik merupakan hal yang penting untuk mengetahui tingkat keberhasilan mahasiswa dalam belajar. Marita dan Shaalih (2008) menyimpulkan bahwa perilaku belajar berpengaruh terhadap tingkat stres kuliah mahasiswa. Jadi jika mahasiswa telah melalui serangkaian proses belajar yang ditempuhnya dengan baik, maka prestasi akademik mahasiswa akan semakin baik. Dari uraian di atas maka hipotesis dua dinyatakan sebagai berikut.

H2: Perilaku belajar berpengaruh positif terhadap tingkat pemahaman mahasiswa akuntansi.

\section{Pengaruh Budaya terhadap Tingkat Pemahaman Akuntansi}

Budaya dapat didefinisikan sebagai pemrograman kolektif dari pikiran yang membedakan anggota satu kelompok manusia dari yang lain (Hofstede 1980). Setiap kelompok manusia memiliki norma-normanya sendiri, yang terdiri dari karakteristik umum, seperti sistem nilai yang diadopsi oleh mayoritas konstituen. Gray berpendapat bahwa nilai-nilai budaya dalam akuntansi pada gilirannya dapat memengaruhi sifat bangsa (Doupnik dan Tsakumis 2004 dalam Marita dan Shaalih 2008). Mahasiswa yang memiliki budaya belajar lebih bagus atau modern, akan lebih bagus dalam memahami mata kuliah akuntansi dibandingkan dengan mahasiswa yang memiliki budaya belajar yang tertinggal. Dari uraian di atas maka hipotesis tiga dinyatakan sebagai berikut.

H3: Budaya berpengaruh positif terhadap tingkat pemahaman mahasiswa akuntansi.

\section{Pengaruh Kecerdasaan Emosi terhadap Tingkat Pemahaman Mahasiswa Akuntansi dengan Kepercayaan Diri sebagai Variabel Pemoderasi}

Terdapat banyak faktor yang dapat memengaruhi kecerdasan emosional. Dalam penelitian ini kepercayaan diri dipilih sebagai salah satu faktor yang akan memengaruhi kecerdasan emosional karena merujuk pada penelitian Goleman (2000). Penelitian tersebut menyatakan bahwa kepercayaan diri adalah kesadaran yang kuat tentang harga dan kemampuan diri sendiri atau kemampuan yang dapat memperkuat atau melemahkan seorang mahasiswa dalam meningkatkan pemahaman akuntansinya dan mencapai tujuan dan cita-citanya. Kepercayaan diri akan menjadi pendorong mahasiswa untuk lebih memahami akuntansi (Maryati 2008). Orang dengan kecakapan ini akan berani tampil dengan keyakinan diri, berani menyatakan keberadaannya, berani menyuarakan pandangan yang tidak populer, bersedia berkorban demi kebenaran serta tegas dan mampu membuat keputusan yang baik 
kendati dalam keadaan tidak pasti. Dari berbagai studi diatas maka hipotesis empat yang akan diuji dalam penelitian ini adalah sebagai beikut.

H4: Kepercayaan diri mahasiswa akuntansi memiliki pengaruh sebagai variabel pemoderasi yang memengaruhi hubungan kecerdasan emosional terhadap tingkat pemahaman mahasiswa akuntansi.

\section{Pengaruh Perilaku Belajar terhadap Tingkat Pemahaman Akuntansi dengan Kepercayaan Diri sebagai Variabel Pemoderasi}

Berbagai penelitian telah dilakukan berkenaan dengan faktor-faktor yang memengaruhi perilaku dan prestasi belajar. Wienn et al. (2006) dalam Maryati (2008) menemukan bahwa masalah-masalah pokok yang mengganggu prestasi akademik mahasiswa di Amerika adalah kebiasaan belajar yang kurang baik yaitu waktu belajar yang tidak teratur (58 persen) dan kebiasaan membaca yang buruk (30 persen). Dampak kebiasaan belajar yang buruk bertambah berat ketika mahasiswa yang berada dalam kebiasaan buruk tersebut berhasil lulus (Calhoun dan Acocella 1995). Menurut Rini (2002) kepercayaan diri adalah sikap positif seorang individu yang memampukan dirinya untuk mengembangkan penilaian positif baik terhadap diri sendiri maupun terhadap lingkungan atau situasi yang dihadapinya. Hal ini bukan berarti bahwa individu tersebut mampu dan kompeten melakukan segala sesuatu seorang diri. Dari berbagai studi diatas, maka hipotesis yang akan diuji dalam penelitian ini adalah sebagai berikut.

H5: Kepercayaan diri mahasiswa akuntansi memiliki pengaruh sebagai variabel moderating yang memengaruhi hubungan perilaku belajar terhadap tingkat pemahaman mahasiswa akuntansi.

\section{Pengaruh Budaya terhadap Tingkat Pemahaman Akuntansi dengan Kepercayaan Diri sebagai Variabel Pemoderasi}

Setiap individu membawa budaya asal mereka masing-masing dalam dunia kerja, yang mencerminkan perilaku sejarah mereka dalam konteks budaya sehingga menjadi budaya nasional (Brannen 1994). Dasar dari pendekatan kognitif budaya adalah bahwa kerangka proses diakuisisi pada satu budaya, kemudian bertahan dan memengaruhi perilaku bahkan mengubah keadaan kontekstual pribadi seseorang. Hal ini kemudian mampu memperkuat atau melemahkan pola pemikiran seseorang dalam menyelesaikan suatu permasalahan atau memahami suatu konsep. Meskipun memiliki budaya belajar yang kurang, namun jika ditunjang dengan tingkat kepercayaan yang tinggi, kemungkinan mahasiswa akan termotivasi untuk lebih memahami akuntansi. Dari penjelasan diatas maka hipotesis yang akan diuji dalam penelitian ini adalah sebagai berikut.

H6: Kepercayaan diri mahasiswa akuntansi memiliki pengaruh sebagai variabel pemoderasi yang memengaruhi hubungan budaya terhadap tingkat pemahaman mahasiswa akuntansi. 


\section{METODA PENELITIAN}

\section{Populasi dan Sampel}

Populasi dalam penelitian ini meliputi mahasiswa program akuntansi di Semarang, Jawa Tengah. Dari seluruh jumlah mahasiswa akuntansi di Semarang, diambil sampel dengan menggunakan metode purposive sampling. Purposive sampling atau pemilihan sampel bertujuan digunakan dalam pemilihan sampel secara tidak acak dengan beberapa kriteria. Kriteria tersebut adalah mahasiswa akuntansi semester VI-VIII, sehingga dapat dianggap telah mendapat manfaat yang maksimal dari mata kuliah yang bermuatan akuntansi dan memiliki diversifikasi tujuan, citacita dan impian hidup, berpikir rasional sebelum bertindak yang semuanya dapat dihubungkan dengan muatan akuntansinya. Kriteria selanjutnya adalah mahasiswa jurusan akuntansi tingkat akhir yang telah menempuh minimal 120 SKS. Mahasiswa yang dipilih diambil dari satu perguruan tinggi swasta dan dua perguruan tinggi negeri di Semarang, yaitu mahasiswa tingkat akhir jurusan akuntansi di Universitas Islam Sultan Agung, Universitas Negeri Semarang dan Universitas Diponegoro. Pemilihan perguruan tinggi tersebut didasarkan oleh pertimbangan sebagai berikut.

a. Perguruan tinggi negeri dan perguruan tinggi swasta di Semarang yang terakreditasi A oleh BAN-PT.

b. Perguruan tinggi tersebut memiliki jurusan S1 akuntansi.

c. Perguruan tinggi ini terjangkau oleh peneliti, sehingga mempermudah pengumpulan data.

d. Perguruan tinggi tersebut memiliki lebih dari 200 mahasiswa akuntansi.

\section{Metoda Pengumpulan Data}

Data dikumpulkan melalui survei dengan menyebarkan kuesioner kepada responden baik melalui perantara (contact person) maupun diberikan secara langsung kepada individu yang bersangkutan. Penyebaran kuesioner dilakukan dengan mendatangi satu persatu calon responden, mengecek apakah calon memenuhi persyaratan sebagai calon responden, lalu menanyakan kesediaanya untuk mengisi kuesioner. Penyebaran kuesioner ini dilakukan oleh peneliti dan dibantu oleh sejumlah rekan peneliti.

\section{Definisi Operasional Variabel}

Variabel kecerdasan emosional diukur dengan lima dimensi kecerdasan emosional (EQ), yang keseluruhannya diturunkan menjadi dua puluh lima kompetensi (Melandy et al., 2007). Kelima dimensi atau komponen tersebut adalah sebagai berikut: pengenalan diri, pengendalian diri, motivasi diri, empati dan kemampuan sosial. Variabel perilaku belajar diukur dari empat dimensi yang berhubungan erat dengan perilaku belajar yaitu: kebiasaan mengikuti pelajaran, kebiasaan memantapkan pelajaran, kebiasaan membaca buku, kebiasaan menyiapkan karya tulis serta kebiasaan menghadapi ujian (Suwarjono 2004). 
Variabel budaya akan lebih dispesifikan dalam segi pengukurannya yaitu dengan menggunakan variabel dummy dengan nilai 1 apabila berlatar belakang suku Jawa dan nilai 0 jika selain suku Jawa. Variabel tingkat pemahaman akuntansi diukur dengan nilai rata-rata mata kuliah Pengantar Akuntansi, Pengantar Akuntansi, Akuntansi Keuangan Menengah, Akuntansi Keuangan Lanjutan, Auditing dan Teori Akuntansi. Variabel kepercayaan diri diukur dengan mengadopdsi 25 pertanyaan berdasarkan penelitian Lauster (2003).

\section{Alat Analisis}

Dalam rangka menguji hipotesis maka model penelitian disajikan pada Gambar 1.

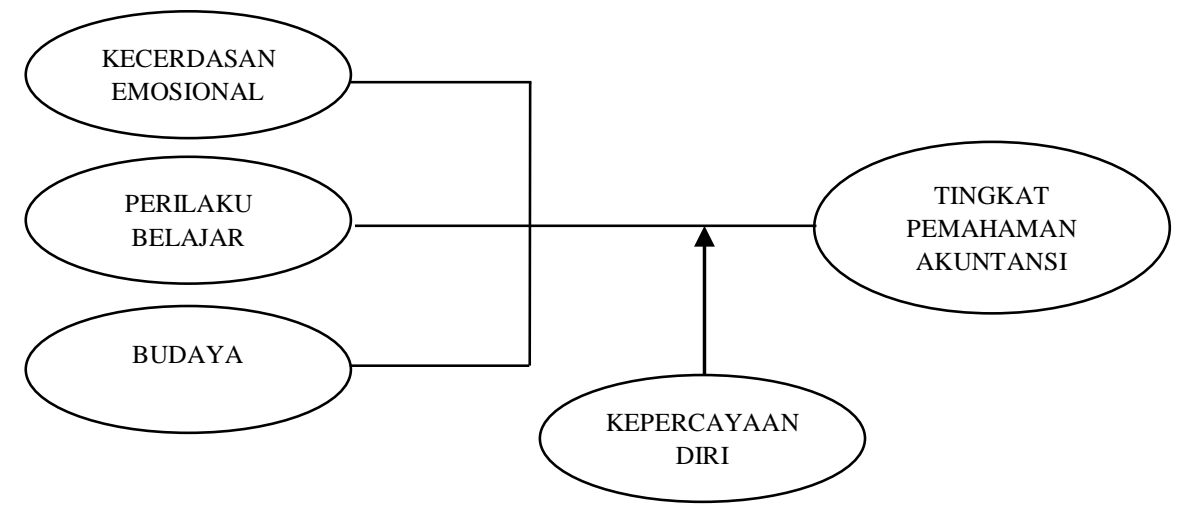

Gambar 1

Kerangka Penelitian

\section{HASIL DAN PEMBAHASAN}

Penelitian ini dilakukan kepada sebanyak 120 orang mahasiswa tingkat akhir yang terdiri dari masing-masing 40 orang mahasiswa dari Universitas Islam Sultan Agung, Universitas Negeri Semarang dan Universitas Diponegoro. Dari 120 kuesioner yang disebarkan, sebanyak 18 kuesioner tidak kembali dan 6 kuesioner kembali tetapi tidak dapat digunakan sehingga sebanyak 96 kuesioner yang digunakan. Dengan demikian penelitian ini memiliki respon rate sebesar 80 persen. Berdasarkan data penelitian, responden yang berasal dari suku/etnik Jawa sebanyak 43 orang atau 44,79 persen. Adapun responden dari suku lainnya (Batak, Tionghoa, Bugis dan suku lain) sebanyak 53 responden atau 55,21 persen. Untuk dapat diuji dengan alat analisis regresi, data penelitian harus lolos uji asumsi klasi. Data dalam penelitian ini sudah bebas dari masalah normalitas, multikolinearitas dan heteroskedalisitas. Dengan demikian uji regresi layak dijalankan, yang hasilnya disajikan dalam Tabel 1 dan Gambar 2 pada lampiran.

Berdasarkan hasil pengujian atas hipotesis pertama (H1) diperoleh nilai $t$ sebesar 2,401 dan nilai signifikansi $\alpha$ sebesar 0,007. Nilai signifikansi pengujian 
hipotesis pertama ternyata lebih kecil dibandingkan nilai taraf signifikansi 0,05. Dengan demikian dapat disimpulkan bahwa H1 didukung oleh hasil penelitian, sehingga terbukti bahwa terdapat pengaruh positif yang signifikan antara kecerdasaan emosional terhadap tingkat pemahaman akuntansi. Artinya dengan semakin tinggi kecerdasan emosional mahasiswa tersebut, maka akan semakin tinggi pula pemahaman yang ia miliki. Dengan demikian kemampuan-kemampuan yang ada dapat menunjang seorang mahasiswa untuk mencapai tujuan dan cita-citanya. Hal ini mengindikasikan bahwa seorang mahasiswa yang kecerdasan emosionalnya tinggi akan berdampak positif pada dirinya untuk mengelola perasaannya, kemampuan untuk memotivasi diri sendiri, kesanggupan untuk tegar dalam menghadapi frustasi, kesanggupan mengendalikan dorongan dan menunda kepuasan sesaat, mengatur suasana hati yang reaktif, serta mampu berempati dan bekerja sama dengan orang lain. Kemampuan-kemampuan ini mendukung seorang mahasiswa dalam berbagai aspek.

Tabel 2

Hasil Pengujian Regresi Berganda

\begin{tabular}{lccl}
\hline \multicolumn{1}{c}{ Variabel } & Nilai $\boldsymbol{t}$ & Sig. $\alpha$ & Hasil \\
\hline Kecerdasan emosional & 2,401 & 0,007 & Hipotesis 1 didukung \\
Perilaku belajar & 3,230 & 0,002 & Hipotesis 2 didukung \\
Budaya & 1,365 & 0,176 & Hipotesis 3 tidak didukung \\
Kecerdasan emosional-kepercayaan diri & 0,009 & 0,993 & Hipotesis 4 tidak didukung \\
Perilaku belajar-kepercayaan diri & 2,907 & 0,005 & Hipotesis 5 didukung \\
Budaya-kepercayaan diri & $-1,216$ & 0,227 & Hipotesis 6 tidak didukung \\
\hline Sumber: hasil pengolahan data penelitian & & &
\end{tabular}

Berdasarkan hasil pengujian hipotesis ke dua (H2), diperoleh nilai t hitung sebesar 3,230 dan nilai signifikansi $\alpha$ sebesar 0,002. Nilai signifikansi pengujian hipotesis ke dua ternyata lebih kecil dibandingkan nilai taraf signifikansi 0,05. Dengan demikian dapat disimpulkan bahwa $\mathrm{H} 2$ didukung oleh hasil penelitian, sehingga terbukti ada pengaruh positif yang signifikan antara perilaku belajar terhadap tingkat pemahaman akuntansi. Semakin tinggi perilaku belajar mahasiswa, maka akan semakin tinggi pula pemahaman yang ia miliki. Dengan demikian kemampuan-kemampuan yang ada dapat menunjang seorang mahasiswa untuk mencapai tujuan dan cita-citanya. Suwardjono (2004) menyatakan bahwa belajar di perguruan tinggi merupakan suatu pilihan srategis dalam mencapai tujuan individual seseorang. Semangat, cara belajar dan sikap mahasiswa terhadap belajar sangat dipengaruhi oleh kesadaran akan adanya tujuan individual dan tujuan lembaga pendidikan yang jelas. Proses belajar mengajar di perguruan tinggi pun jelas merupakan salah satu solusi yang akan membekali mahasiswa dengan ilmu pengetahuan, pemahaman dan ketrampilan teknis sesuai bidangnya untuk mengkonfirmasi pemahaman mahasiswa dalam proses belajar mandiri. Kemudian 
seorang mahasiswa harus merefleksikan kemauan tersebut dalam sesuatu yang hendak dicapainya dengan suatu perbuatan yang apabila tercapai akan memuaskan dirinya sendiri.

Berdasarkan hasil pengujian hipotesis ke tiga (H3), diperoleh nilai t hitung sebesar 1,365 dan nilai signifikansi $\alpha$ sebesar 0,176. Nilai signifikansi pengujian hipotesis ke tiga ternyata lebih besar dibandingkan nilai taraf signifikansi 0,05. Dengan demikian dapat disimpulkan bahwa H3 tidak didukung hasil penelitian, sehingga tidak terbukti adanya pengaruh positif yang signifikan antara budaya terhadap tingkat pemahaman akuntansi. Variabel budaya yang indikatornya terdiri dari Jawa dan selain Jawa belum bisa dioperasionalkan secara empiris untuk dijadikan tolok ukur yang signifikan dalam hal pengaruhnya terhadap sistem perkembangan akuntansi. Hal ini disebabkan karena setiap etnis/suku memiliki cara masing-masing dalam proses belajar mengajarnya guna mencapai cita-cita yang diinginkan serta mempunyai implementasi kerangka yang koheren untuk mengorganisasikan aktivitas kehidupan etnis itu sendiri. Penjelasan diatas pun didukung bahwa budaya telah didefinisikan sebagai pemrograman kolektif pikiran yang membedakan antara satu kelompok atau individu manusia yang satu dengan yang lainnya sedangkan tingkat integrasi dan kemampuan berfikir masing-masing budaya bervariasi antara masyarakat/individu yang satu dengan yang lainnya (Hofstede 1980).

Berdasarkan hasil pengujian hipotesis ke empat (H4) diperoleh nilai t hitung sebesar 0,009 dan nilai signifikansi $\alpha$ sebesar 0,993. Nilai signifikansi pengujian hipotesis ke empat ternyata lebih besar dibandingkan nilai taraf signifikansi 0,05. Dengan demikian dapat disimpulkan bahwa H4 ditolak, sehingga kepercayaan diri bukan merupakan variabel moderating antara kecerdasan emosional dengan tingkat pemahaman akuntansi. Kecerdasaan emosional yang tinggi dengan kepercayaan diri yang lemah, tidak akan menutup kemampuan seorang mahasiswa untuk tidak mampu memahami bidang yang akan ia tempuh. Hal ini disebabkan karena pemahaman akuntansi yang ditinjau dari mata kuliah seperti Pengantar Akuntansi, Akuntansi Keuangan Menengah, Akuntansi Keuangan Lanjutan dan Auditing sarat dengan ilmu-ilmu teknis yang dapat diartikan bahwa ilmu-ilmu tersebut selalu berhubungan dengan angka, logika, analitis dan teori-teori yang keseluruhannya selalu menggunakan otak kiri. Adapun kepercayaan diri tergolong dalam feeling atau perasaan dan intuisi yang keyakinannya selalu menggunakan otak kanan dalam mengolah atau mengeksplorasi segala jenis permasalahan yang dihadapi. Berbeda dengan kecerdasaan emosional yang apabila kadarnya semakin tinggi berarti kecerdasaan emosional tersebut dikendalikan oleh logika yang artinya menggunakan otak kiri untuk berfikir. Sebaliknya apabila kadar emosionalnya semakin rendah, berarti kecerdasaan emosional tersebut dikendalikan oleh feeling yang artinya menggunakan otak kanan untuk berfikir (Djamarah 2002). 
Berdasarkan hasil pengujian hipotesis ke lima (H5), diperoleh nilai t hitung sebesar 2,907 dan nilai signifikansi $\alpha$ sebesar 0,005. Nilai signifikansi pengujian hipotesis ke lima ternyata lebih kecil dibandingkan nilai taraf signifikansi 0,05. Dengan demikian dapat disimpulkan bahwa H5 didukung hasil penelitian, sehingga terbukti bahwa kepercayaan diri merupakan variabel moderating antara perilaku dengan tingkat pemahaman akuntansi. Kepercayaan diri memiliki pengaruh yang signifikan dalam hal memoderasi antara perilaku belajar terhadap pemahaman akuntansi. Sehingga apabila kepercayaan diri mahasiswa tersebut semakin kuat maka akan semakin tinggi pula tingkat pemahaman yang ia miliki. Hal ini disebabkan karena kepercayaan diri adalah sikap positif seseorang individu yang memampukan dirinya untuk mengembangkan penilaian positif, baik terhadap diri sendiri maupun terhadap lingkungan atau situasi yang dihadapinya. Hal ini bukan berarti bahwa individu tersebut mampu dan kompeten melakukan segala sesuatu seorang diri. Hasil ini mendukung penelitian yang menyatakan perilaku belajar berpengaruh terhadap tingkat pemahaman akuntansi.

Berdasarkan hasil pengujian hipotesis ke enam (H6) diperoleh nilai t hitung sebesar -1,216 dan nilai signifikansi $\alpha$ sebesar 0,227. Nilai signifikansi pengujian hipotesis ke enam ternyata lebih besar dibandingkan nilai taraf signifikansi 0,05. Dengan demikian dapat disimpulkan bahwa H6 tidak didukung oleh hasil penelitian, sehingga kepercayaan diri bukan merupakan variabel moderating antara budaya dengan tingkat pemahaman akuntansi. Kepercayaan diri tidak memiliki pengaruh yang signifikan dalam hal memoderasi antara budaya terhadap pemahaman akuntansi. Sehingga apabila kepercayaan diri mahasiswa tersebut tinggi maka tidak akan memberikan pengaruh terhadap peningkatan pemahaman yang ia miliki. Hal ini sering disebabkan karena kepercayaan diri mempunyai banyak karakteriristik sifat yang dapat berubah sewaktu-waktu tergantung mood (mobile feel) atau tidak selalu bersifat positif. Mereka mempercayai diri sendiri sebagai katalisator, penggerak dan pelopor, serta merasa bahwa kemampuan-kemampuan mereka lebih unggul dibanding kebanyakan orang lain. Orang yang terlalu percaya diri, ada kalanya sering bertindak tidak hati-hati dan bertingkah laku seenaknya. Tingkah laku mereka sering menyebabkan konflik dengan orang lain. Seseorang yang bertindak dengan kepercayaan pada diri sendiri yang berlebihan, sering memberikan kesan kejam dan lebih banyak punya lawan dari pada teman (Lauster 2003).

\section{SIMPULAN}

Berdasarkan hasil penelitian yang telah dilakukan, maka dapat dibuat simpulan sebagai berikut ini. Pertama, terdapat pengaruh positif secara signifikan antara kecerdasan emosional terhadap tingkat pemahaman akuntansi. Kedua, terdapat pengaruh positif secara signifikan antara perilaku belajar terhadap tingkat pemahaman akuntansi. Ketiga, tidak terdapat pengaruh positif secara signifikan 
antara budaya terhadap tingkat pemahaman akuntansi dan variabel moderating antara kecerdasan emosional dengan tingkat pemahaman akuntansi. Variabel kepercayaan diri merupakan variabel moderating antara perilaku belajar dengan tingkat pemahaman akuntansi. Variabel kepercayaan diri bukan merupakan variabel moderating antara budaya dengan tingkat pemahaman akuntansi.

Berdasarkan hasil penelitian yang telah dilakukan, maka saran yang dapat diberikan untuk penelitian selanjutnya dapat berusaha menambah jumlah sampel dan jumlah sampel atau memperluas daerah penelitian agar diperoleh hasil yang lebih bervariasi misalnya: membandingkan universitas berbasis religiositas dan universitas non religiositas (nasional).

\section{DAFTAR PUSTAKA}

Djamarah. 2002. Psikologi Belajar. Jakarta: PT Rineka Cipta.

Goleman, D. 2000. Working With Emotional Intelegence. Terjemahan Alex Tri Kantjono W. Jakarta: PT Gramedia Pustaka Utama.

Kroeber, A. L. dan C. Kluckhohn. 1952. Culture: A Critical Review of Concepts and Action. Cambridge: The Museum.

Lutfi, A. A. 2007. Pengaruh kecerdasan emosional dan kecerdasan spiritual terhadap tingkat pemahaman akuntansi. Skripsi. Fakultas Ekonomi Universitas Islam Sultan Agung. Semarang (tidak dipublikasikan).

Marita, S. S., dan H. S. Shaalih. 2008. Kajian empiris atas perilaku belajar dan kecerdasaan emosional dalam mempengaruhi stres kuliah. Prosiding Simposium Nasional Akuntansi VII.

Maryati, I. 2008. Hubungan antara kecerdasan emosi dan keyakinan diri (self efficacy) dengan kreativitas pada siswa akselerasi. Skripsi. Fakultas Psikologi Universitas Muhammadiyah. Surakarta (tidak dipublikasikan).

Melandy, R., F. Widiastuti, dan N. Aziza. 2007. Sinkronisasi komponen kecerdasan emosional dan pengaruhnya terhadap tingkat pemahaman akuntansi dalam sistem pendidikan tinggi akuntansi. Prosiding Simposium Nasional Akuntansi $X$.

Suryaningsum, S., S. Heriningsih, dan A. Afuah. 2004. Pengaruh pendidikan tinggi akuntansi terhadap kecerdasan emosional mahasiswa. Prosiding Simposium Nasional Akuntansi VII.

Suyanti, E. 2006. Pengaruh perilaku belajar terhadap prestasi akademik mahasiswa akutansi. Skripsi. Fakultas Ekonomi Universitas Islam Sultan Agung, Semarang (tidak dipublikasikan). 
Tikollah, M. R., I. Triyuwono, dan U. Ludigdo. 2006. Pengaruh kecerdasan intelektual, kecerdasan emosional, dan kecerdasan spiritual terhadap sikap etis mahasiswa akuntansi. Prosiding Simposium Nasional Akuntansi IX.

Trisniwati, I. E., dan S. Suryaningsum. 2003. Pengaruh kecerdasan emosional terhadap tingkat pemahaman akutansi. Prosiding Simposium Nasional Akuntansi VII.

Yulianti. 2002. Kecerdasan emosional dan stres kerja. Tesis. Pascasarjana MM UGM. 


\section{LAMPIRAN}

Tabel 1

Hasil Normalitas dan Multikolinearitas

\begin{tabular}{lc}
\hline \multicolumn{1}{c}{ Indikator } & Nilai Statistik \\
\hline Pengujian One-Sample Kolmogorov Smirnov \\
Nilai $Z$ & 0,792 \\
Signifikansi 2 sisi & 0,557 \\
Pengujian Multikolinearitas & \\
VIF kecerdasan emosional & 2,518 \\
VIF perilaku belajar & 2,888 \\
VIF budaya & 1,015 \\
VIF kepercayaan diri & 2,459 \\
\hline
\end{tabular}

Sumber: data primer yang diolah

Scatterplot

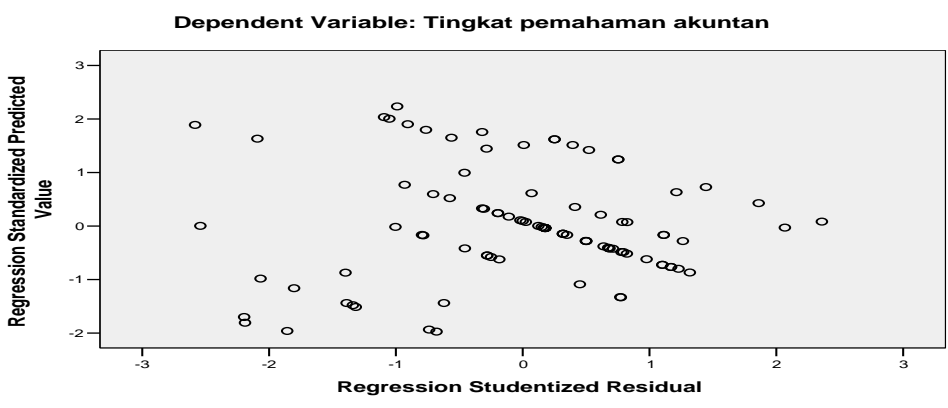

Gambar 2

Scatterplot Pengujian Heteroskedastisitas 
